\title{
Influence of Five Adulterants on Detection and Quantification of Tramadol in Urine Samples
}

\author{
Mohammed A. Abdel Ati' ${ }^{1}$, Maha A. Hilal ${ }^{1}$, Khaled M. Mohamed ${ }^{2}$, and Reda M. Elsayed, ${ }^{1}$ \\ ${ }^{1}$ Forensic Medicine and Clinical Toxicology Department,Faculty of Medicine ,Sohag University ,Sohag ,Egypt. \\ ${ }^{2}$ College of Forensic Sciences-Naif Arab University for Security Sciences, Ryadh ,Saudi Arabia.
}

\begin{abstract}
Background: There is a growing evidence of abuse of tramadol in some African and West Asian countries considering large seizures of such preparations in North and West Africa especially in Egypt. Urine testing for drugs of abuse has become an integral weapon in the nation's war against drugs. A limitation inherent in all urine drug testing is the possibility of sample adulteration or substitution. Aim of study: To detect qualitative and quantitative effects of five adulterants on positive urine samples for tramadol. Subject and Method(s): This study was conducted in Clinical Toxicology Laboratory in Sohag University Hospitals. The samples were tested for its integrity by checking PH, specific gravity and creatinine. The samples were tested by RIA then confirmed and quantified by HPLC. Results: Urine samples adulterated with vinegar, drano and liquid hand soap generated false negative results by immunoassay testing. HPLC confirmation showed decrease tramadol conc. below limit of quantification in urine samples adulterated with $40 \%$ vinegar and $40 \%$ drano. Conclusion: Some adulterants make it easy to produce false negative results and the specimen integrity testing is inadequate in detection of these adulterants.
\end{abstract}

Key words Drug abuse, Tramadol detection, Urine adulteration, HPLC confirmation

\section{Introduction}

$\checkmark$ ubstance abuse in Egypt is a serious public health threat. Recent studies have demonstrated increase $\checkmark$ in the prevalence of the use of cannabis and tramadol (Saleh, 2015).

Tramadol is a centrally acting analgesic with a multimode of action. It acts on serotonergic and noradrenergic nociception, while its metabolite O-desmethyl tramadol acts on the $\mu$-opioid receptor (Babalonis et al., 2013).

Tramadol is generally considered as a medicinal drug with a low potential for dependence relative to morphine. Nevertheless, tramadol dependence may occur when used for prolonged periods of time (more than several weeks to months). Dependence to tramadol may occur when used within the recommended dose range of tramadol but especially when used at supra-therapeutic doses (Alvarado et al., 2005).

There is growing evidence of abuse of tramadol in some African and West Asian countries considering large seizures of such preparations in North and West Africa. Abuse of tramadol is reported by Egypt, Gaza, Jordan, Lebanon, Libya, Mauritius, Saudi Arabia and Ghana (Elliason et al., 2018).

According to Nabil et al., (2015) the prevalence of tramadol dependency according to all substance abusers was $49 \%$. The prevalence of comorbid psychiatric disorders was $43 \%$.
Urine testing for drugs of abuse has become an integral weapon in the nation's war against drugs. These drug tests are used in pre-employment screening, postaccident assessment, probation control, and inmate determent (Wong, 2002).

Drug testing occurs in two phases: screening and confirmation. Historically, the initial screen has been a chemical test or immunoassay (IA) that can provide a reasonable turnaround time with minimal labor and resources (Al-khayal et al., 2017).

A limitation inherent in all urine drug testing is the possibility of sample adulteration or substitution (Jaffee et al., 2007).

Adulteration process is defined as the tampering or manipulation of a urine sample with the intention of changing the test results. Urine sample adulteration is very serious problem in forensic urine drug testing process. Sample adulteration is usually performed by substitution, dilution or the addition of adulterants agents including so called "masking agents" sold commercially (Ragab et al., 2018).

The use of adulterant agents can cause false negative results in drug tests by either interfering with the screening test procedure and/or destroying the drugs present in the urine sample (Yee et al., 2014). 


\section{Aim of the Work}

To detect qualitative and quantitative effects of five adulterants on positive urine samples for tramadol.

\section{Subjects and Methods}

This study was conducted in Clinical Toxicology Laboratory in Sohag University Hospitals. Acceptable samples had the following criteria: from 10-100ml urine in volume, voided in a clean dry labeled container without preservative. The samples were tested by immunoassay for tramadol, positive samples only were included. Urine samples were tested for integrity including measurement of ( $\mathrm{PH}$, specific gravity, creatinine) before testing.

Five Types of adulterants were used.

- Vinegar, bleach, visine eye drops and liquid drano at 3 concentrations $10 \%, 20 \%$ and $40 \%$.

- $\quad$ Liquid hand soap at 3 conc. 5\%, 10\% and 20\%.

These adulterants levels were selected to obtain an accurate representation of real-world samples adulteration as it would easy to be brought in a small container and added to the urine samples.

- To prepare adulterated samples, $1 \mathrm{~mL}$ aliquots were obtained from the urine samples for each drug. $1 \mathrm{ml}$ of the unadulterated urine sample was used to determine the initial concentration of the drug by High Performance Liquid Chromatography (HPLC). The total volume of the adulterated samples was maintained at $1 \mathrm{ml}$. The amount of liquid adulterants was added to the urine sample to reach the $1 \mathrm{ml}$ limit. The $10 \% \mathrm{v} / \mathrm{v}$ sample had $900 \mu \mathrm{L}$ of urine and 100 $\mu \mathrm{L}$ of adulterant. This process was followed for the remaining concentrations: $20 \% \mathrm{v} / \mathrm{v}(800: 200) 40 \%$ v/v (600:400) and 5\%v/v (950:50).

Screening of tramadol in urine samples by immunoassay:

Apparatus: Radio immunoassay apparatus using drug analyzer: (CDx90), Thermofisher Scientific co. supplier AMG Company.

Fully automated random access analyzer, dedicated drug testing system (photometric).

Serial number 7218-0150 present in Clinical Toxicology Laboratory in Sohag University Hospital.

i- Principle of procedure:

This assay is a semi-quantitative assay based on the competition of Tramadol labeled enzyme glucose -6phosphate dehydrogenase (G6PDH) and the free drug in the urine sample for the fixed amount of antibody binding sites.

In the absence of the free drug in the sample, the antibody binds the drug enzyme conjugate and enzyme activity is inhibited. The enzyme (G6PDH) activity is determined at 340nm spectrophotometrically by the conversion of NAD to NADH

ii- Calibration: Figure (A)

1- Construct the calibration curve (log-logit mode) by using the following calibrators:

Negative Urine Calibrator.

$100 \mathrm{ng} / \mathrm{ml}$ Urine Calibrator.
200 ng/ml Urine Calibrator (Cutoff calibrator).

500 ng/ml Urine Calibrator.

1000 ng/ml Urine Calibrator.

2- For qualitative analysis use the $200 \mathrm{ng} / \mathrm{ml}$ calibrator as a cutoff level to distinguish "positive" and "negative" specimens.

3- Check the constructed calibration curve using the provided QC materials 150, 250ng/ml.as $150 \mathrm{ng} / \mathrm{ml}$ considered LQC which control negative results and HQC250 ng/ml control positive results.

Each conc. of each adulterant was added separately to urine sample and the samples were examined for specimen integrity then retested by immunoassay where cut off for tramadol detection was $200 \mathrm{ng} / \mathrm{ml}$ above it considered positive and below it considered negative and finally the samples were confirmed by HPLC.

Confirmation and quantiatication of tramadol in urine samples by HPLC:

Apparatus: High Performance Liquid Chromatography (HPLC) (Agilent; USA): Consisted of an Agilent technologies 1200 series quaternary pump combined with an Agilent 1200 series photo diode array detector (USA), an Agilent 1200 series vacuum degasser (USA) and an Agilent autosampler injector. Chromatographic separation was performed on a Zorbax SB C8 $(250 \mathrm{~mm} \times 4.6 \mathrm{~mm}, 5 \mu \mathrm{m})$ column (USA). HPLC present in Sohag Clinical Toxicology Lab- Sohag University Hospitals.

i- Calibrators and quality control

A stock solution of tramadol (T), o-desmethyl tramadol (ODT) and propranolol used as internal standard (IS) were prepared at a concentration of $1 \mathrm{mg} / \mathrm{mL}$ in methanol and kept stored at -20C. Intermediate standards at concentration. of $100 \mathrm{mg} / \mathrm{mL}$ for each analyte were prepared in methanol by diluting from $1.0 \mathrm{mg} / \mathrm{mL}$ stock standards. Different stock standards were used to. Prepare quality control samples (QCs) at the same concentrations. Working calibrators (250, 500, 750, 1000, 1500 and $2000 \mathrm{ng} / \mathrm{mL}$ ) of T and ODT were made by a serial dilution of the intermediate solution with drug free human urine. QCs were prepared from a separate stock solution at concentrations of 450, 900 and 1800 $\mathrm{ng} / \mathrm{mL}$. A working standard solution of $5.00 \mathrm{Ug} / \mathrm{mL}$ propranolol (IS) was prepared by diluting propranolol stock solution with distilled water.

ii- Phosphate buffer preparation:

Phosphate buffer $(0.01 \mathrm{M})$ was prepared by dissolving $1.36 \mathrm{~g}$ ( $0.01 \mathrm{~mol})$ of potassium dihydrogen phosphate in $1 \mathrm{~L}$ deionized water.

iii- Extraction procedure

To 10 -mL polypropylene tubes added $1.0 \mathrm{~mL}$ of urine, $75 \mathrm{~mL}$ of $5 \mathrm{Ug} / \mathrm{mL}$ propranolol (IS), $100 \mathrm{~mL}$ of conc. ammonium hydroxide (33\%) and $6.0 \mathrm{~mL}$ of MTBE. The tubes were then mixed by rotator at the rate of $40 \mathrm{rpm}$ for 20-min and centrifuged at $3200 \mathrm{rpm}$ for 5-min. The organic layer was transferred to $10-\mathrm{mL}$ polypropylene tube containing $0.5 \mathrm{~mL}$ of $1.0 \mathrm{M}$ hydrochloric acid. The 
tubes were then vortex mixed for 5-min and centrifuged at $3200 \mathrm{rpm}$ for 5 -min. The organic layer was discarded. To the remaining aqueous solution, $150 \mathrm{~mL}$ of conc. ammonium hydroxide and $2.0 \mathrm{~mL}$ of MTBE were added. The tubes were then centrifuged at $3200 \mathrm{rpm}$ for 5 -min. The organic layer was transferred to 5 -mL glass tubes and evaporated to dryness. The dried extracts were reconstituted in $200 \mathrm{~mL}$ acetonitrile, vortex mixed for 30-s and $100 \mathrm{~mL}$ was injected into the HPLC system.

- Check PH at every step and adjust it according to result.

iv- HPLC analysis:

Chromatography condition:

The column oven temperature was maintained at $25{ }^{\circ} \mathrm{C}$. The mobile phase consisted of ACN: phosphate buffer $(40: 60, \mathrm{v} / \mathrm{v})$ at a flow rate of $0.5 \mathrm{~mL} / \mathrm{min}$. The detector was set to scan from 200 to $360 \mathrm{~nm}$ and had a discrete channel set at $218 \mathrm{~nm}$, which was the wavelength used for quantification.

Calibration curve construction: Figure (B)

Linearity of the method was investigated by evaluation of the regression line and expresses by coefficient of determination (r2). Linearity was achieved with a minimal r2 of 0.993. Calibration curves were prepared by spiking blank urine with corresponding analytical working solutions to obtain calibration concentrations within 250-2000 ng/mL. Negative QCs were analyzed after each linearity sample to evaluate potential carry-over.

\section{Results}

Specimen integrity test:

A. Effect of vinegar on specimen integrity tests

- Addition of $40 \%$ vinegar to urine samples lead to decrease in $\mathrm{PH}$ and creatinine below their normal range while specific gravity increased.

- Addition of $20 \%$ vinegar also lead to decrease in $\mathrm{PH}$ and increase in specific gravity but creatinine level was not affected.

- Finally addition of $10 \%$ vinegar has no effect on $\mathrm{PH}$, specific gravity, or creatinine.

B. Effect of bleach on specimen integrity tests

- Addition of $40 \%$ bleach to urine samples lead to increase in $\mathrm{PH}$ and specific gravity above their normal range while creatinine decreased.

- Addition of $20 \%$ bleach also lead to increase in $\mathrm{PH}$ and specific gravity but creatinine level was not affected.

- Finally addition of $10 \%$ bleach has no effect on $\mathrm{PH}$, specific gravity, or creatinine.

C. Effect of visine on specimen integrity tests

Addition of visine to urine samples has no effect on $\mathrm{PH}$, specific gravity, or creatinine.

D. Effect of drano on specimen integrity tests

- Addition of $40 \%$ drano to urine samples lead to increase in $\mathrm{PH}$ above normal range while specific gravity and creatinine decreased.
- Addition of $20 \%$ drano also lead to increase in $\mathrm{PH}$ but specific gravity and creatinine decreased.

- Finally addition of $10 \%$ drano has no effect on PH, specific gravity, or creatinine.

E. Effect of liquid hand soap on specimen integrity tests

- Addition of $20 \%$ liquid hand soap to urine samples lead to increase in $\mathrm{PH}$ and specific gravity above their normal range while creatinine level decreased.

- Addition of $10 \%$ liquid hand soap also leads to increase in $\mathrm{PH}$ and specific gravity while creatinine level not affected.

- Finally addition of 5\% liquid hand soap has no effect on $\mathrm{PH}$ or creatinine and increase in specific gravity.

Immunoassay screening for tramadol:

1. The parent sample concentration was $530 \mathrm{ng} / \mathrm{ml}$. (as the method of detection considered semiquantitative not only screening).

2. Addition of vinegar at high conc. $40 \%$ is able to successfully masking positive response of tramadol in tested urine samples. While moderate conc.20\% and low conc.10\% cannot affect tramadol detection in urine samples as shown in table (1) and figure (1).

3. On other hand addition of bleach, visine whatever their conc. failed to mask tramadol detection by immunoassay as shown in table (1) and figure (1).

4. For drano it was effective for decreasing the response rate for tramadol using immunoassay method at high conc. $40 \%$ and moderate $20 \%$. While $10 \%$ is still has no effect on tramadol result.as shown in table (1) and figure (1).

5. Unfortunately, addition of liquid hand soap by any conc. even low conc. up to5\% can mask tramadol detection by immunoassay giving false negative results.as shown in table (2) and figure (1).

Detection and quantification tramadol and O-des methyl tramadol (ODT) by HPLC:

- The parent positive sample conc. was: Tramadol 494ng/ml and ODT $804 \mathrm{ng} / \mathrm{ml}$ Figure (4).

- Limit of detection (LOD): $150 \mathrm{ng} / \mathrm{ml}$

- Limit of quantification (LOQ): $250 \mathrm{ng} / \mathrm{ml}$

- $150 \mathrm{ng} / \mathrm{ml}-250 \mathrm{ng} / \mathrm{ml}$ : The drug can be detected but cannot be quantified.

1- Effect of vinegar on Tramadol and ODT detection \& quantification by HPLC

- After addition of vinegar in conc. $40 \%$ leading to decrease in conc. of tramadol to less than LOQ but still be detectable $(192.2 \mathrm{ng} / \mathrm{ml})$. For ODT also decrease to more or less half the actual conc. (479.5ng/ml).

- While addition of $20 \%$ vinegar decrease tramadol conc. more or less half the actual conc. (257.5 $\mathrm{ng} / \mathrm{ml})$. For ODT decrease to lesser degree (636.4).

- Finally $10 \%$ has the least effect as there is minimal decrease from actual conc. $(439.7 \mathrm{ng} / \mathrm{ml})$ and more or less the same occurred in ODT conc. $(690.5 \mathrm{ng} / \mathrm{ml})$.As shown in table (3) and figures (5,6\&7). 
2- Effect of bleach on Tramadol and ODT detection \& quantification by HPLC

- After Addition of bleach in conc.40\% decrease tramadol conc. to $(300.5 \mathrm{ng} / \mathrm{ml})$. For ODT also decrease to more or less half the actual conc.(465.2ng/ml).

- While addition of $20 \%$ bleach decrease tramadol conc. to $(392.5 \mathrm{ng} / \mathrm{ml})$ and for ODT decrease to less degree (637.4ng/ml).

- Finally $10 \%$ has the least effect as there is minimal decrease from actual conc. (437.6ng/ml) and more or less the same occurred in ODT conc. (656.5ng/ml). As shown in table (3) and Figures (8,9\&10).

3- Effect of visine on Tramadol and ODT detection\& quantification by HPLC

After Addition of visine in conc.40\% decrease tramadol conc. to $(301.8 \mathrm{ng} / \mathrm{ml})$.and for ODT also decrease to more or less half the actual conc. (474.3 $\mathrm{ng} / \mathrm{ml})$.

- While addition of $20 \%$ visine decrease tramadol conc. to $(389.7 \mathrm{ng} / \mathrm{ml})$ and for ODT decrease to less degree $(631.5 \mathrm{ng} / \mathrm{ml})$.

- Finally $10 \%$ has the least effect as there is minimal decrease from actual conc. (451.2ng/ml) and more or less the same occurred in ODT conc. (677.2ng/ml). As shown in table (3) and figures (11,12\&13).

4- Effect of drano on Tramadol and ODT detection \& quantification by HPLC

- Addition of drano in conc.40\% leading to decrease in conc. of tramadol to less than LOQ but still be detectable (231.2 ng/ml).and for ODT also decrease to more than half the actual conc.(332.1ng/ml).

- While addition of $20 \%$ drano cause moderate decrease in tramadol conc $(398.4 \mathrm{ng} / \mathrm{ml})$ and for ODT decrease to less degree $(645.2 \mathrm{ng} / \mathrm{ml})$.

- Finally $10 \%$ has the least effect as there is minimal decrease from actual conc. $(433.1 \mathrm{ng} / \mathrm{ml})$ and more or less the same occurred in ODT conc. $(685.4 \mathrm{ng} / \mathrm{ml})$ as shown in table (3) and figures (14,15 \& 16).

5- Effect of liquid hand soap on Tramadol and ODT detection \& quantification by HPLC

- Addition of liquid hand soap in conc.20\% leading to moderate decrease in conc. of tramadol (323.6 $\mathrm{ng} / \mathrm{ml}$ ) and mareked decrease in ODT conc. (359.1ng/ml).

- While addition of $10 \%$ liquid hand soap cause decrease in tramadol conc. to $(414.9 \mathrm{ng} / \mathrm{ml})$ and for ODT moderate decrease to $(439.6 \mathrm{ng} / \mathrm{ml})$.

- Finally $5 \%$ has the least effect on tramadol as there is minimal decrease from actual conc. (432.4ng/ml) and moderate decrease in ODT conc. $(507.7 \mathrm{ng} / \mathrm{ml})$.As shown in table (4) and figures (17, 18\&19).

Statistical study for influence of different adulterants on Tramadol and ODT quantification by HPLC showing that addition of vinegar, drano and liquid hand soap decrease tramadol and ODT significantly with increased concentration as shown in table (5).

Table (1): Effects of different adulterants conc. on tramadol detection by RIA

\begin{tabular}{|c|c|c|c|c|}
\hline Adulterant Conc. & Vinegar & Bleach & Visine & Drano \\
\hline \multirow{2}{*}{$40 \%$} & 153ng/ml & 320ng/ml & 351ng/ml & 91ng/ml \\
\hline & (Negative) & (Positive) & (Positive) & (Negative) \\
\hline \multirow{2}{*}{$20 \%$} & 363ng/ml & $401 \mathrm{ng} / \mathrm{ml}$ & 409ng/ml & 133ng/ml \\
\hline & (Positive) & (Positive) & (Positive) & (Negative) \\
\hline \multirow{2}{*}{$10 \%$} & $415 \mathrm{ng} / \mathrm{ml}$ & $451 \mathrm{ng} / \mathrm{ml}$ & 459ng/ml & $251 \mathrm{ng} / \mathrm{ml}$ \\
\hline & (Positive) & (Positive) & (Positive) & (Positive) \\
\hline
\end{tabular}

Table (2): Effect of liquid hand soap conc. on tramadol detection by RIA

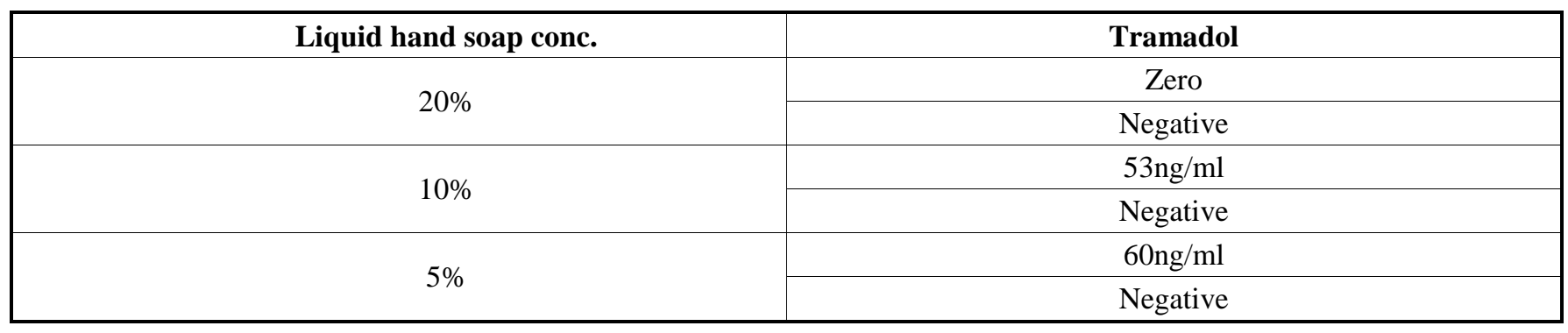


Table (3): Effect of different adulterants conc. on tramadol and o-des methyl tramadol (ODT) detection and quantification by HPL

\begin{tabular}{|c|c|c|c|c|c|c|c|c|c|}
\hline \multicolumn{2}{|c|}{ Conc./adulterant } & \multicolumn{2}{c|}{ Vinegar } & \multicolumn{2}{c|}{ Bleach } & \multicolumn{2}{c|}{ Visine } & \multicolumn{2}{c|}{ Drano } \\
\hline \multirow{2}{*}{$40 \%$} & Tramadol & 190 & $-\mathrm{ve}$ & 300.5 & $+\mathrm{ve}$ & 301.8 & $+\mathrm{ve}$ & 231.2 & $+\mathrm{ve}$ \\
\cline { 2 - 10 } & ODT & 479.5 & $+\mathrm{ve}$ & 465.2 & $+\mathrm{ve}$ & 474.3 & $+\mathrm{ve}$ & 332.1 & $+\mathrm{ve}$ \\
\hline \multirow{2}{*}{$20 \%$} & Tramadol & 257.5 & $+\mathrm{ve}$ & 392.5 & $+\mathrm{ve}$ & 389.7 & $+\mathrm{ve}$ & 398.4 & $+\mathrm{ve}$ \\
\cline { 2 - 10 } & ODT & 636.4 & $+\mathrm{ve}$ & 637.4 & $+\mathrm{ve}$ & 631.5 & $+\mathrm{ve}$ & 645.2 & $+\mathrm{ve}$ \\
\hline \multirow{2}{*}{$10 \%$} & Tramadol & 439.7 & $+\mathrm{ve}$ & 437.6 & $+\mathrm{ve}$ & 451.2 & $+\mathrm{ve}$ & 433.1 & $+\mathrm{ve}$ \\
\cline { 2 - 9 } & ODT & 690.5 & $+\mathrm{ve}$ & 656.5 & $+\mathrm{ve}$ & 677.2 & $+\mathrm{ve}$ & 685.4 & $+\mathrm{ve}$ \\
\hline
\end{tabular}

Table (4): Effect of liquid hand soap conc. on tramadol and o-des methyl tramadol (ODT) detection and quantification by HPLC

\begin{tabular}{|c|c|c|c|}
\hline \multicolumn{2}{|c|}{ Conc./adulterant } & \multicolumn{2}{|c|}{ liquid hand soap } \\
\hline \multirow{2}{*}{$20 \%$} & Tramadol & 323.6 & +ve \\
\cline { 2 - 4 } & ODT & 359.1 & $+\mathrm{ve}$ \\
\hline \multirow{2}{*}{$10 \%$} & Tramadol & 414.9 & $+\mathrm{ve}$ \\
\cline { 2 - 4 } & ODT & 439.6 & $+\mathrm{ve}$ \\
\hline \multirow{2}{*}{$5 \%$} & Tramadol & 432.4 & $+\mathrm{ve}$ \\
\cline { 2 - 4 } & ODT & 507.7 & $+\mathrm{ve}$ \\
\hline
\end{tabular}

Table (5): Statistical study for influence of adulterants on tramadol and ODT quantification by HPLC.

\begin{tabular}{|c|c|c|c|}
\hline Adulterant & $\begin{array}{c}\text { Sample size } \\
\text { (N) }\end{array}$ & $\begin{array}{c}\text { Pearson correlation } \\
\text { (tramadol) }\end{array}$ & $\begin{array}{c}\text { Pearson correlation } \\
\text { (ODT) }\end{array}$ \\
\hline Vinegar & 12 & -0.972 & -0.994 \\
\hline Bleach & 12 & -0.669 & -0.743 \\
\hline Visine & 12 & -0.721 & -0.811 \\
\hline Drano & 12 & -0.997 & -0.895 \\
\hline Liquid hand soap & 12 & -0.851 & -0.876 \\
\hline
\end{tabular}

Significance at $1 \%$ level

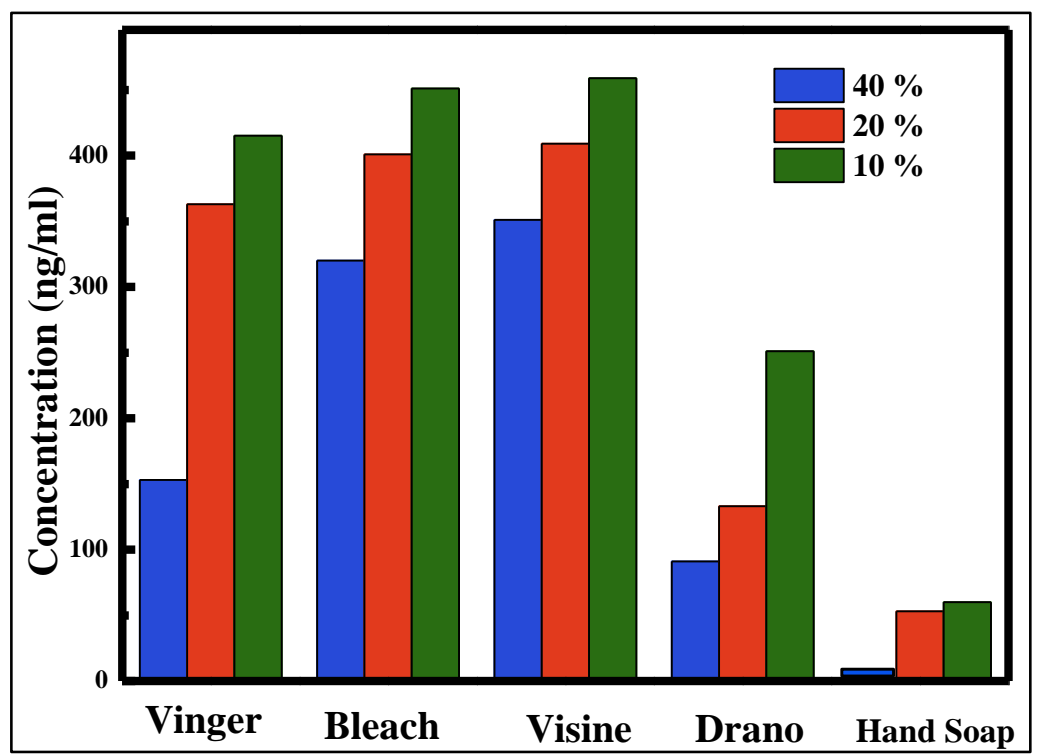

Figure (1): Effects of different adulterants on tramadol detection by RIA 


\section{HPLC Figures}

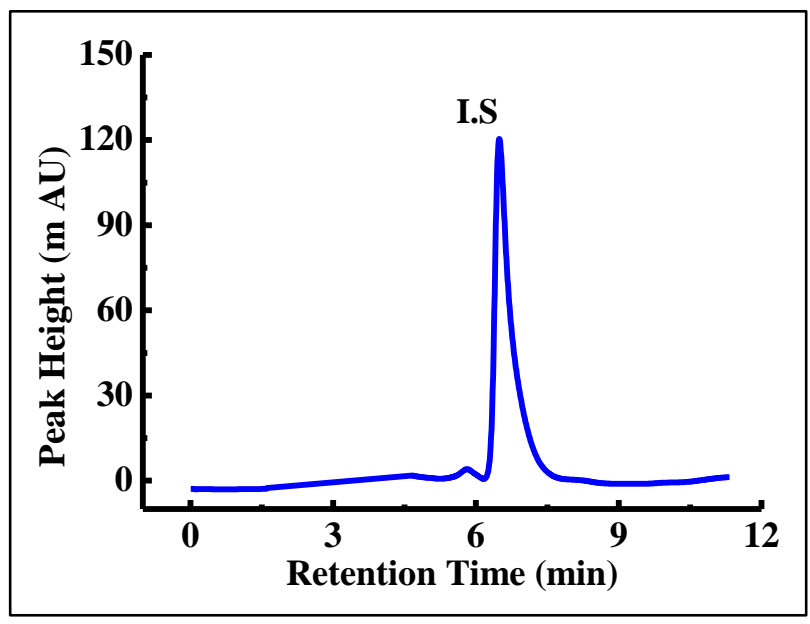

Figure (2): Chromatogram for negative quality control (blank urine)

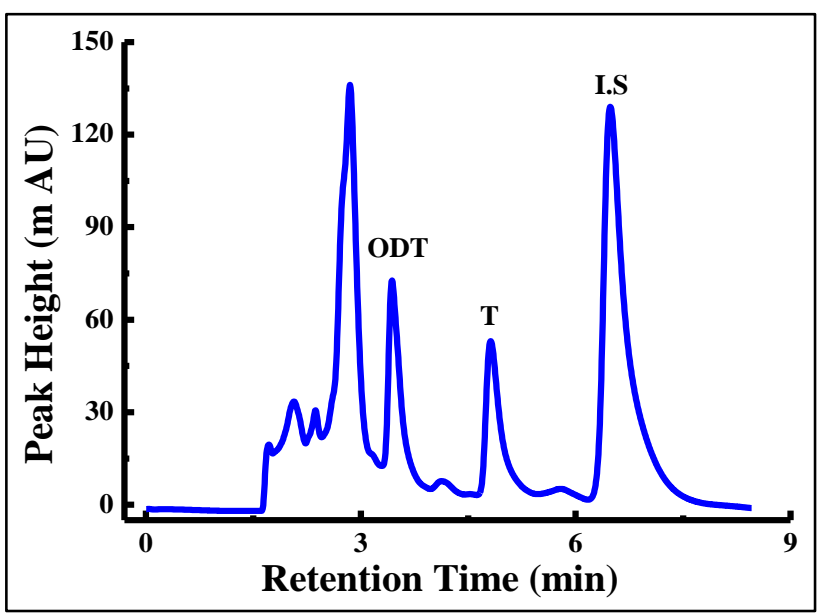

Figure (4):Chromatogram for the parent sample (Tramadol conc. 494ng/ml ODT conc. 804ng/ml)

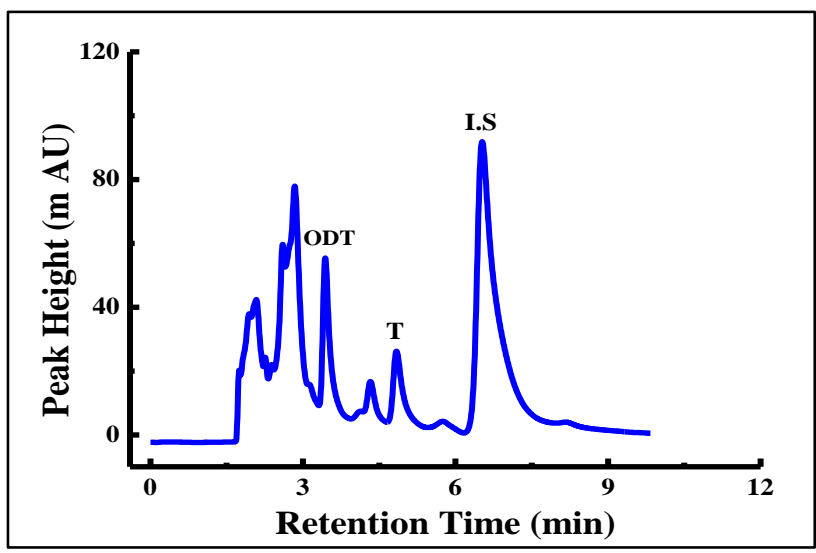

Figure (6): Chromatogram for parent sample after addition of $20 \%$ vinegar

(Tramadol conc. $257.5 \mathrm{ng} / \mathrm{ml} \&$ ODT conc.636.4ng/ml)

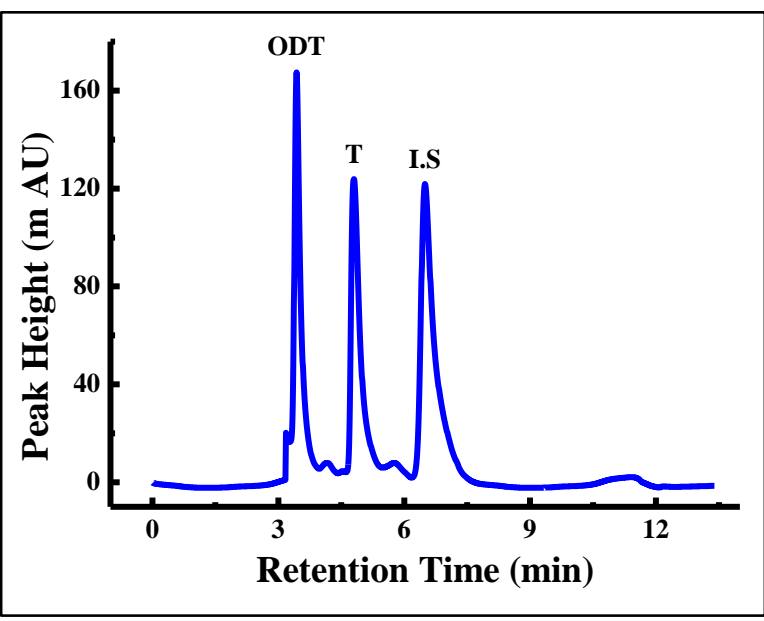

Figure (3): Chromatogram for one calibrator 1000ng/ml

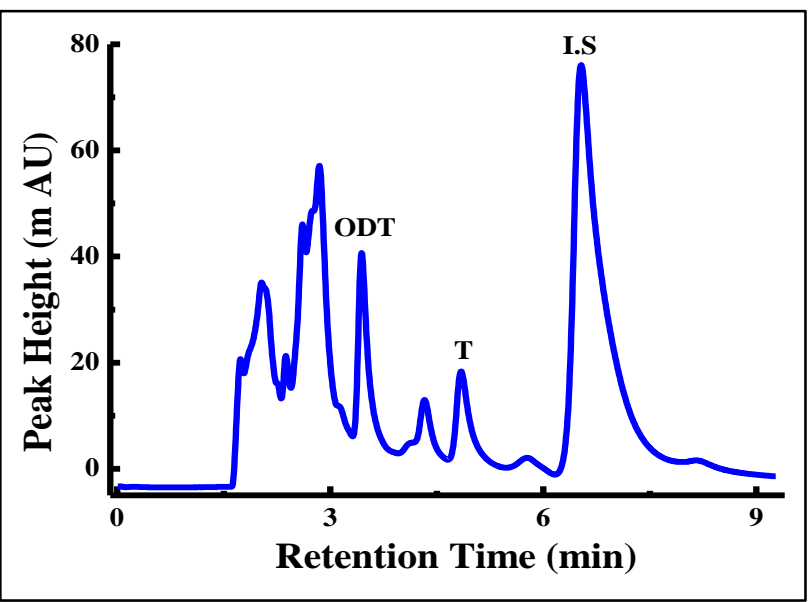

Figure (5): Chromatogram for parent sample after addition of $40 \%$ vinegar

(Tramadol conc. 192.2ng/ml \&ODT conc.479.5ng/ml)

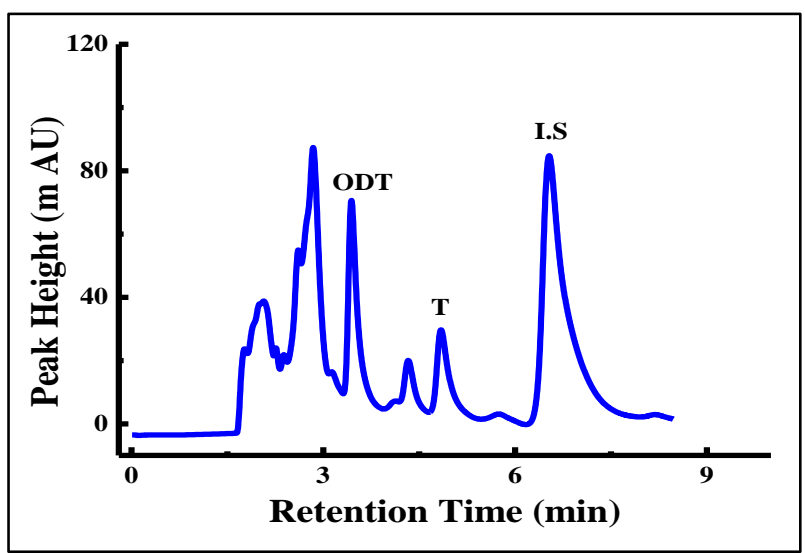

Figure (7): Chromatogram for parent sample after addition of $10 \%$ vinegar

(Tramadol conc. 439.7ng/ml \& ODT conc.690.5ng/ml) 


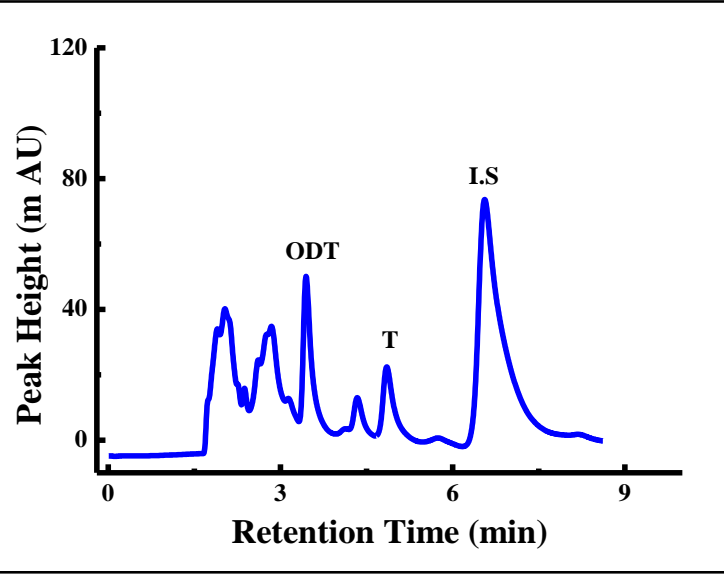

Figure (8):Chromatogram for parent sample after addition of $40 \%$ bleach

(Tramadol conc.300.5 ng/ml \&ODTconc.465.2 ng/ml)

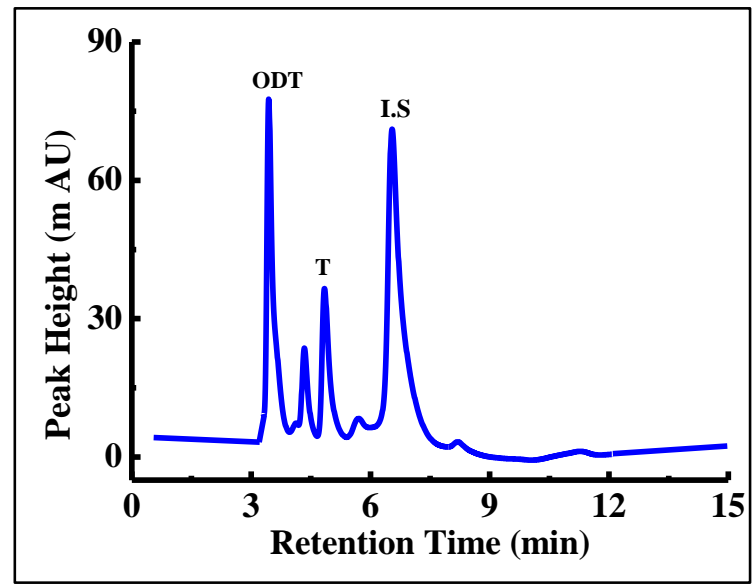

Figure(10): Chromatogram for parent sample after addition of $10 \%$ bleach

(Tramadol conc. 437.6ng/ml \& ODT conc.656.5ng/ml)

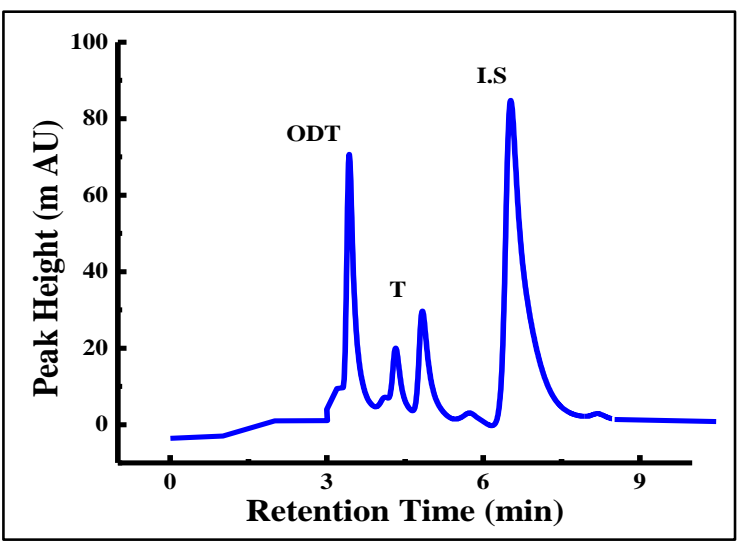

Figure (12): Chromatogram for parent sample after addition of $20 \%$ visine

(Tramadol conc. 389.7ng/ml \& ODT conc.631.5.ng/ml)

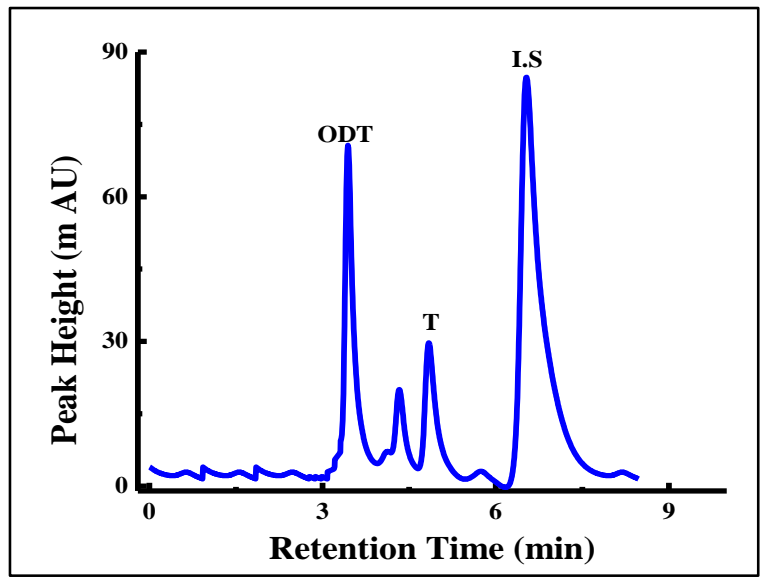

Figure (9): Chromatogram for parent sample after addition of $20 \%$ bleach

(Tramadol conc. 392.5 ng/ml \&ODTconc.637.4 ng/ml)

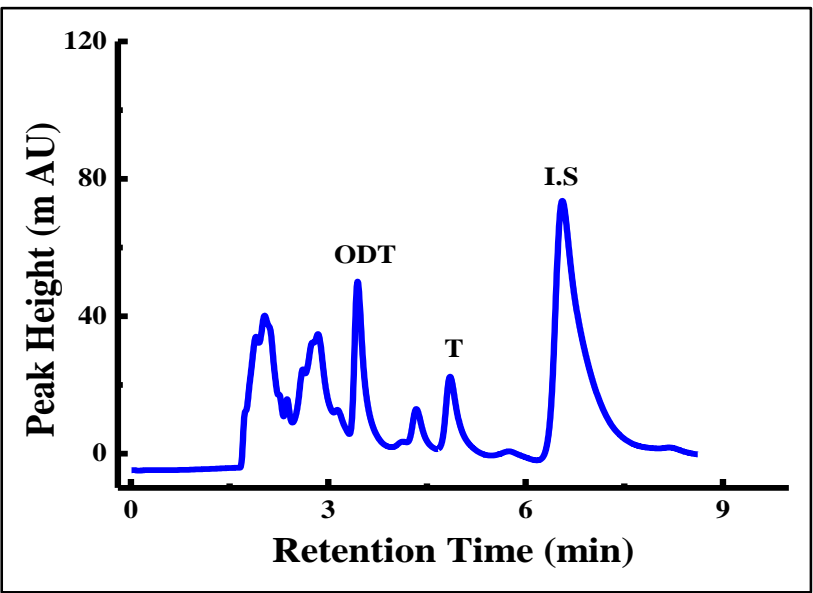

Figure (11): Chromatogram for parent sample after addition of $40 \%$ visine

(Tramadol conc.301.8 ng/ml \& ODT conc. $474.3 \mathrm{ng} / \mathrm{ml}$ )

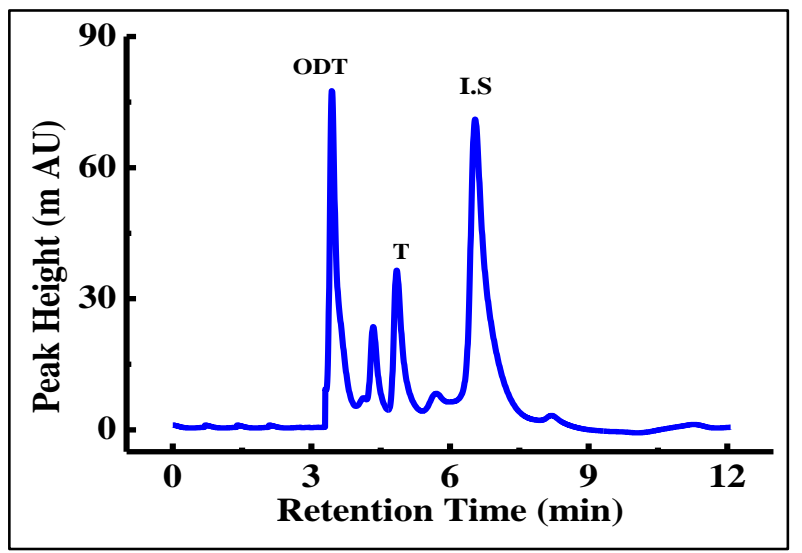

Figure (13): Chromatogram for parent sample after addition of $10 \%$ visine

(Tramadol conc. $451.2 \mathrm{ng} / \mathrm{ml} \&$ ODT conc. 677.2ngl/ml) 


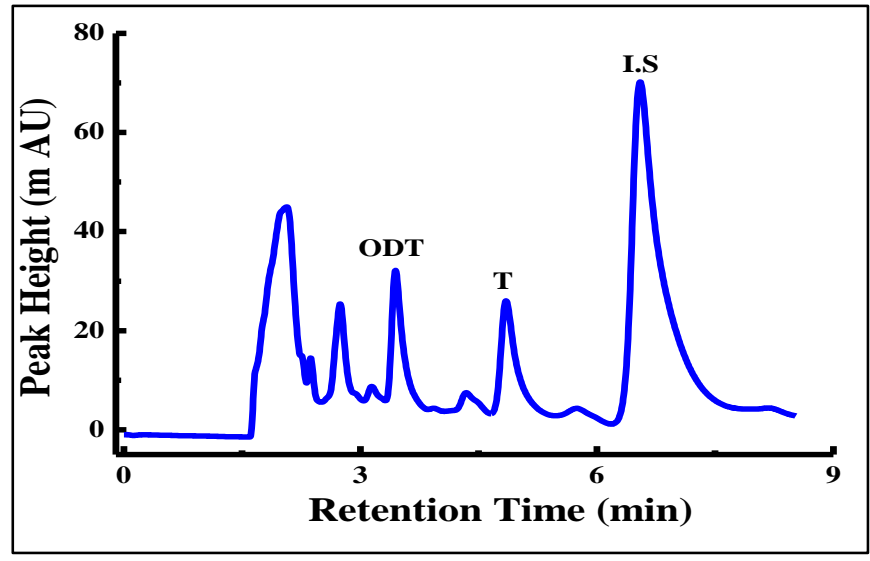

Figure (14):Chromatogram for parent sample after addition of $40 \%$ drano

(Tramadol conc.231.2 ng/ml \&ODT conc.332.1 ng/ml)

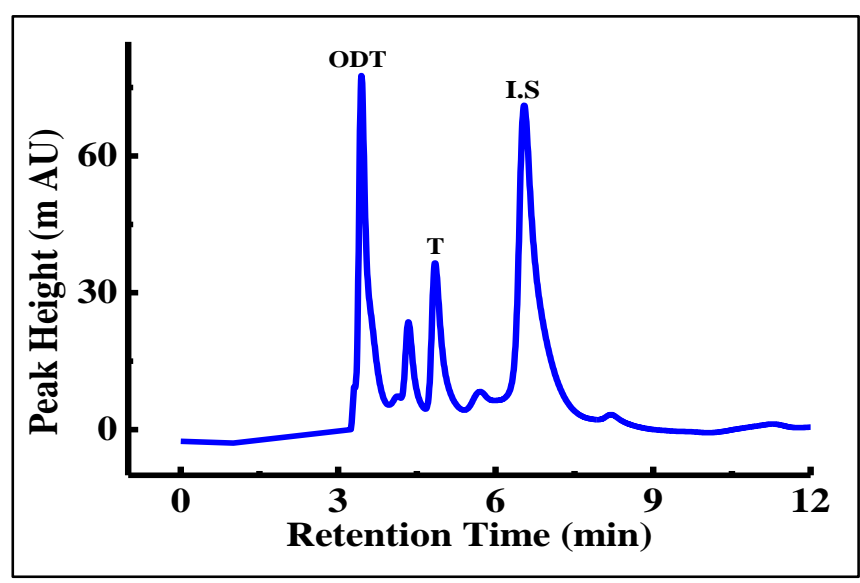

Figure(16):Chromatogram for parent sample after addition of $10 \%$ drano

(Tramadol conc.433.1 ng/ml \&ODT conc.685.4ng/ml)

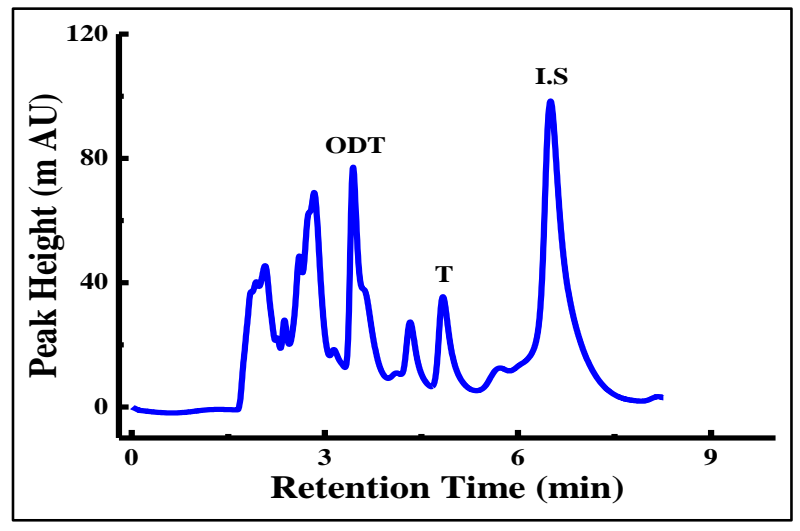

Figure (18):Chromatogram for parent sample after addition of $10 \%$ liquid hand soap

(Tramadol conc.414.9 ng/ml \&ODTconc.439.6ng/ml)

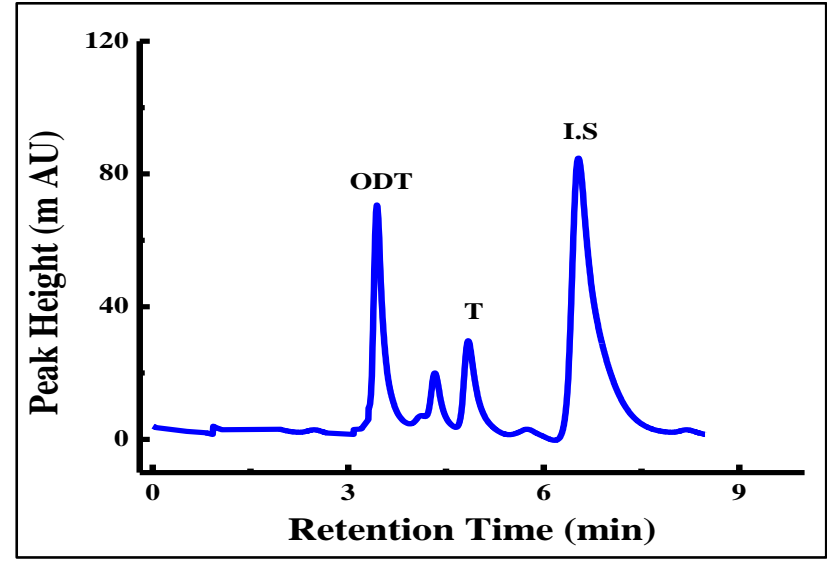

Figure (15):Chromatogram for parent sample after addition of $20 \%$ drano

(Tramadol conc. $398.4 \mathrm{ng} / \mathrm{ml}$ \&ODT conc.645.2ng/ml)

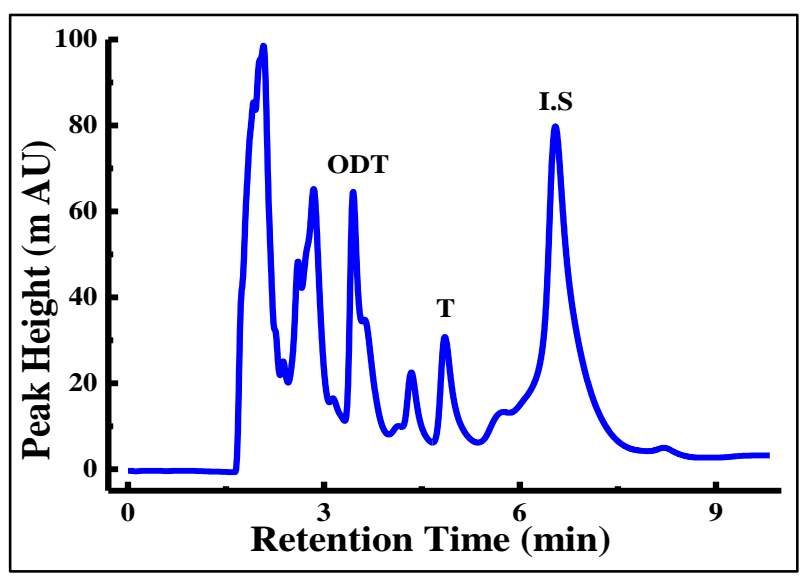

Figure (17):Chromatogram for parent sample after addition of $20 \%$ liquid hand soap

(Tramadol conc.323.6 ng/ml \&ODTconc.359.1ng/ml)

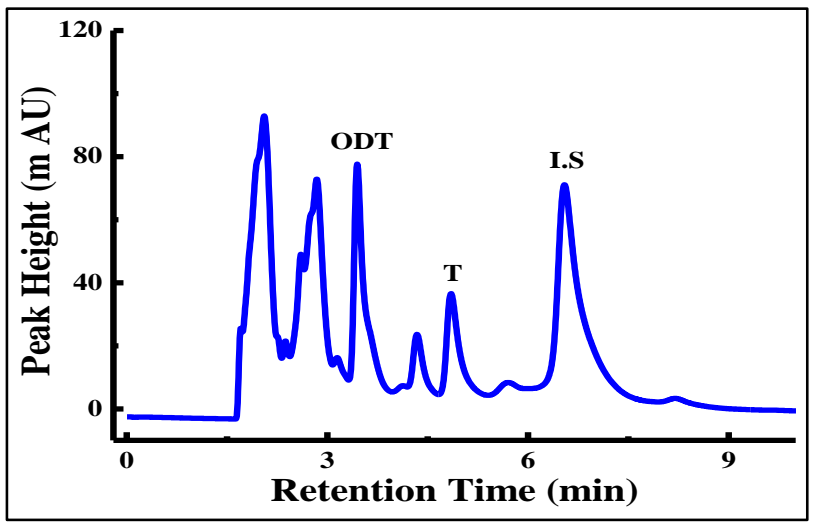

Figure (19): Chromatogram for parent sample after addition of $5 \%$ liquid hand soap

(Tramadol conc.432.4 ng/ml \& ODTconc 507.7ng/ml) 


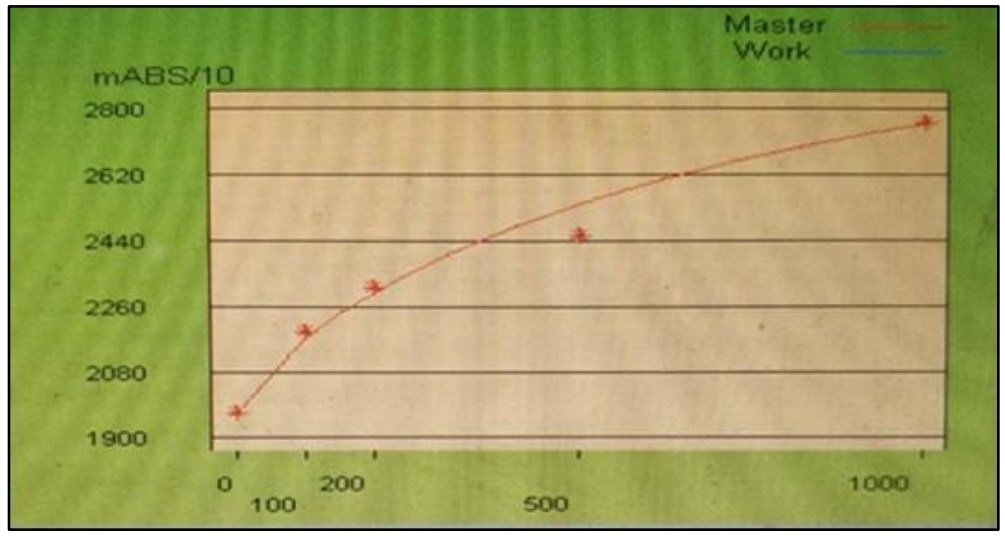

Figure (A): Tramadol calibration curve on radioimmunoassay.

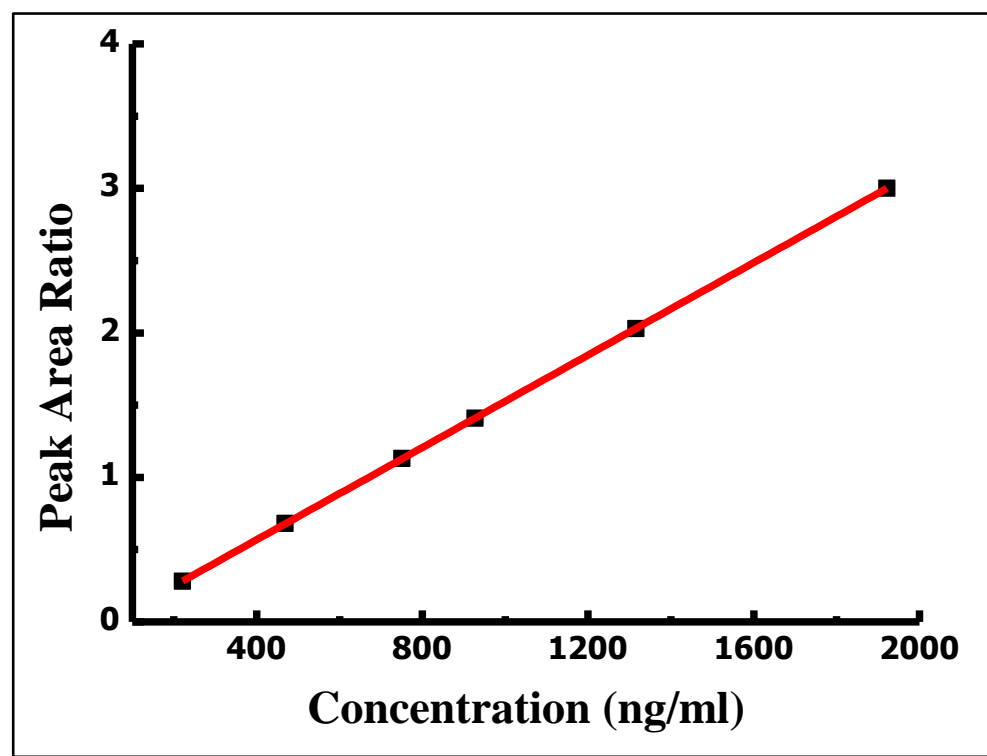

Figure (B): Tramadol calibration curve on HPLC

\section{Discussion}

Regarding effect of vinegar on specimen integrity tests: addition of $40 \%$ vinegar to urine samples lead to decrease in $\mathrm{PH}$ and creatinine below their normal range while specific gravity increased, addition of $20 \%$ vinegar also lead to decrease in $\mathrm{PH}$ and increase in specific gravity but creatinine level not affected and, finally addition of $10 \%$ vinegar has no effect on $\mathrm{PH}$, specific gravity, nor creatinine.

The above result is in consistent with Olivieri et al ., (2018) who found that vinegar appears to lower $\mathrm{pH}$ levels, which can affect binding, reaction times, and drug solubility.

Considering radio immunoassay screening for tramadol in this study: addition of vinegar at high conc. $40 \% \mathrm{v} / \mathrm{v}$ is able to successfully masking positive response of tramadol in tested urine samples, while moderate conc. $20 \%$ and low conc.10\% cannot affect tramadol detection in urine samples.
However HPLC reveals that addition of vinegar in conc. $40 \%$ leading to decrease in conc. of tramadol to less than LOQ but still be detectable (192.2 $\mathrm{ng} / \mathrm{ml})$, and for ODT also decrease to more or less half the actual conc. (479.5ng/ml), while addition of $20 \%$ vinegar decrease tramadol conc. more or less half the actual conc. $(257.5 \mathrm{ng} / \mathrm{ml})$ and for ODT decrease to less degree (636.4). Finally addition of $10 \%$ has the least effect as there is minimal decrease from actual conc. Of tramadol $(439.7 \mathrm{ng} / \mathrm{ml})$ and more or less the same occurred in ODT conc(690.5ng/ml).

This was in agreement with Paul et al., (2000) who noticed considerable decrease in free opioids at a lower PH. In other research, Thabet et al., (2016) reported increase in the acidity causes highly significant reduction in the drug level.

Regarding effect of bleach on specimen integrity tests: addition of $40 \%$ bleach to urine samples lead to increase in $\mathrm{PH}$ and specific gravity above their 
normal range while creatinine decreased. Addition of $20 \%$ bleach also lead to increase in $\mathrm{PH}$ and specific gravity but creatinine level not affected and finally, addition of $10 \%$ bleach has no effect on $\mathrm{PH}$, specific gravity, or creatinine. On other hand addition of bleach whatever its conc. failed to mask tramadol detection by immunoassay.

However HPLC reveals that addition of bleach in conc. $40 \%$ decrease tramadol conc. to $(300.5 \mathrm{ng} / \mathrm{ml})$.and for ODT also decrease to more or less half the actual conc. (465.2ng/ml), addition of $20 \%$ bleach decrease tramadol conc. to $(392.5 \mathrm{ng} / \mathrm{ml})$ and for ODT decrease to less degree $(637.4 \mathrm{ng} / \mathrm{ml})$. Finally $10 \%$ has the least effect as there is minimal decrease from actual conc. $(437.6 \mathrm{ng} / \mathrm{ml})$ and more or less the same occurred in ODT conc. (656.5ng/ml).

In contrary to the above results, olivieri et al., (2018) stated that bleach is extremely effective in adulterating urine screens positive for benzodiazepines, cocaine, THC and opiates in the EIA.

This is in consistent with Thabet et al., (2016) who reported increase in alkalinity causes apparent increase in drug level in case of high tramadol concentration.

Furthermore, addition of visine to urine samples has no effect on $\mathrm{PH}$, specific gravity, nor creatinine, and these results matching with El Khateeb and Arafa, (2019).

On other hand in contrary to El Khateeb and Arafa, (2019) addition of visine eye drops failed to mask tramadol detection by immunoassay. Addition of visine in conc. $40 \%$ decrease tramadol conc. to $(301.8 \mathrm{ng} / \mathrm{ml})$, and for ODT also decrease to more or less half the actual conc. $(474.3 \mathrm{ng} / \mathrm{ml})$. While addition of $20 \%$ visine decreases tramadol conc. (389.7ng/ml), and for ODT decrease to less degree $(631.5 \mathrm{ng} / \mathrm{ml})$. Finally $10 \%$ has the least effect as there is minimal decrease from actual conc. $(451.2 \mathrm{ng} / \mathrm{ml})$ and more or less the same occurred in ODT conc $(677.2 \mathrm{ng} / \mathrm{ml})$.

The active ingredient in Visine eye drops is tetrahydro-zoline hydrochloride, which relieves redness and irritation by constricting blood vessels. However, Dasgupta, (2007) reported that the mechanism of adulteration is most likely due to the inactive ingredients benzalkonium chloride and borate. Visine is effective at masking THC metabolites, but not other drugs, across various immunoassays.

Regarding effect of drano on specimen integrity tests: addition of $40 \%$ drano to urine samples lead to increase in $\mathrm{PH}$ above normal range while specific gravity and creatinine decreased. Also, addition of $20 \%$ drano also lead to increase in $\mathrm{PH}$ but specific gravity and creatinine decreased. Finally addition of $10 \%$ drano has no effect on $\mathrm{PH}$, specific gravity, nor creatinine.In consistent with $\mathbf{F u}$ et al., (2014) Drano causes change to alkaline $\mathrm{pH}$ in urine samples, which may affect reaction rates, drug solubility, and binding. It is also effective for decreasing the response rate for tramadol using immunoassay method at high conc.

$40 \%$ and moderate conc. $20 \%$ while $10 \%$ is still has no effect on tramadol result.

However, HPLC found that addition of drano in conc. $40 \%$ leading to decrease in conc. of tramadol to less than LOQ but still be detectable $(231.2 \mathrm{ng} / \mathrm{ml})$.and for ODT also decrease to more than half the actual conc. (332.1ng/ml).

While addition of $20 \%$ drano causes moderate decrease in tramadol conc. (398.4 ng/ml) and for ODT decrease to less degree $(645.2 \mathrm{ng} / \mathrm{ml})$.

Finally $10 \%$ has the least effect as there is minimal decrease from actual conc. (433.1ng/ml) and more or less the same occurred in ODT conc. (685.4ng/ml).

In consistent with Oliveri et al., (2018) who stated that drano has been reported to cause strong adulterating effects on EIA. Also he suggest that Drano's oxidation reaction to the drug assays is the primary mechanism of adulteration.

For effect of liquid hand soap on specimen integrity tests, in consistent with Dasgupta (2010) who reported that soap may alter $\mathrm{pH}$ levels in urine samples and may also interfere with drug binding on immunoassay. in the present sturdy it was found that addition of $20 \%$ liquid hand soap to urine samples lead to increase in $\mathrm{PH}$ and specific gravity above their normal range while creatinine level decreased. Addition of $10 \%$ liquid hand soap also lead to increase in $\mathrm{PH}$ and specific gravity while creatinine level not affected and finally addition of 5\% liquid hand soap has no effect on PH nor creatinine and increase in specific gravity.

Unfortunately, in consistent with $W u$ (2003) who stated that dishwashing detergent adulteration has caused false-negative results across a variety of drug assays using the CEDIA, including screens for many drugs including tramadol (amphetamine, barbiturates, cocaine, opiates, PCP, and THC) we also found that addition of liquid hand soap by any conc. even low conc. up to $5 \%$ can mask tramadol detection by immunoassay giving false negative results.

However, HPLC results reveals that addition of liquid hand soap in conc. $20 \%$ leading to moderate decrease in conc. of tramadol (323.6 ng/ml) and marked decrease in ODT conc. $(359.1 \mathrm{ng} / \mathrm{ml})$, while addition of $10 \%$ liquid hand soap cause decrease in tramadol conc. to (414.9 $\mathrm{ng} / \mathrm{ml})$ and for ODT moderate decrease to (439.6 $\mathrm{ng} / \mathrm{ml})$. Finally $5 \%$ has the least effect on tramadol as there is minimal decrease from actual conc. $(432.4 \mathrm{ng} / \mathrm{ml})$ and moderate decrease in ODT conc. (507.7ng/ml).

Most detergents and soaps contain multiple ingredients including surfactants, suspending agents, alkaline builders, and optical brighteners. Soaps and detergents have been reported to create both falsenegative and false-positive results on several different immunoassays. 


\section{Conclusion}

The current study concludes that some adulterants make it easy to produce false negative results and the specimen integrity testing is inadequate in detection of these adulterants.

\section{References}

Al-khayal R., Al-Mousa F., Attia A.and Ragab A., (2017): Efficiency evaluation of urine collection vessels with impeded urine adulteration/ substance of abuse (SOA) rapid detection test strips. Journal of Drug Abuse. 3 (2): 1-9.

Alvarado C., Guzman A., Diaz E., Patino R. (2005): Synthesis of tramadol and analogous. J Mex Chem Soc. 49(4): 324-327.

Babalonis S., Lofwall M.R., Nuzzo P.A. and Siegel A.J. (2013):Abuse liability and reinforcing efficacy of oral tramadol in humans. Drug Alcohol Depend. 129(1-2): 116-124.

Dasgupta A., (2007): The effects of adulterants and selected ingested compounds on drugs-of-abuse testing in urine. Am J Clin Pathol. 128(3):491503.

Dasgupta A., (2010): Household Chemicals and Internet Based Products for Beating Urine Drug Tests. In: Beating drug tests and defending positive results.ch (5):61-78

Elliason E., Sandow B., Asechaab T., Kpangkpari S. and Asiaktiwen R., (2018): Abuse and Misuse of Tramadol among the Youth in the Wassa Amenfi West Municipality in the Western Region of Ghana. Psychol Psychology Res Int J.3 (7):1-18.

El-Khateeb S.A. and Arafa,M.A., (2019):Influence of Zinc and Some Commercial Products on Tramadol and Apetryl Detection in Human Urine Samples . Egypt J. Forensic Sci. Appli. Toxicol.19 (2):43-56.

$\mathrm{Fu}$ S., Luong S., Pham A., Charlton N. and Kuzhiumparambil U., (2014): Bioanalysis of urine samples after manipulation by oxidizing chemicals: Technical considerations. Bioanalysis. 6: 1543.

Jaffee B. W., Trucco E., Levy S. and Weiss R. D., (2007): Is this urine really negative? A systematic review of tampering methods in urine drug screening and testing .Journal of Substance Abuse Treatment. 33(1):33-42.
Nabil R., Lamia G., Amro S., Mohamed S.and Mohammad M., (2015): An epidemiological study of tramadol $\mathrm{HCl}$ dependence in an outpatient addiction clinic at Heliopolis Psychiatric Hospital. Menoufia Medical Journal. 28:591-596.

Olivieri B., Maric M. and Bridge C., (2018): Determining the effects of adulterants on drug detection via ELISA and adulterant tests strips. Drug Testing and Analysis. 10(9):1-25

Paul B.D., Martin K.K. and Maguilo J.J., (2000): Effects of pyridinium chlorochromate adulterant (Urine Luck) on testing of drugs of abuse and a method for quantitative detection of chromium (VI) in urine. J Anal Toxicol., 24:233-237.

Ragab A., Al-khayyal,R., Al-Mousa F. and Bahriz A., (2018): Urine samples tampering pattern for drugs of abuse testing: experience of the Saudi Arabia Poison Control Centers. J. Addict. Res. Ther. 9(1): 355-359.

Saleh D., Irene A. Christofer A., (2015): Substance use by Egyptian youth: current patterns and potential avenues for prevention. Substance Use \& Misuse J.,50(5):609-618.

Thabet H.Z., Mohamed A.A. and Abd-El-hameed S.Y., (2016): Effect of some methods of adultration on tramadol detection in urine by drug of abuse test cards and immunoassay. Zagazig Journal of Forensic Medicine \& Toxicology,14 (1): 29- 41.

Wong R., (2002): The effect of adulterants on urine screen for drugs of abuse: Detection by an onsite dipstick device. American clinical laboratory J., 20:37-39.

Wu A., (2003):Urine Adulteration and Substitution Prior to Drugs of Abuse Testing. Journal of Clinical Ligand Assay.26:11-18.

Yee D., Atayee R.S., Best B. and Ma J., (2014): Observations on the urine metabolic profile of codeine in pain patients. J. Anal. Toxicol., 38: 86-91. 


\section{تاثير خمسة من المواد الثائبة على الكثف عن الترامادول وقياسه كميته فى عينات البول}

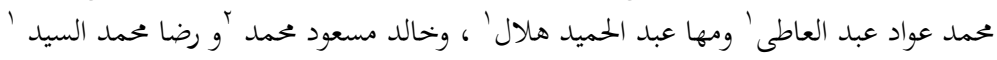

\section{الملخص العربي}

المقدمة: تزايدت في الاونة الاخيرة نسب تعاطي الترامادول في بعض دول أفريقيا وغرب آسيا مع الأخذ في الاعتبار ضبط كميات كبيرة من الترامادول في شمال وغرب إفريقيا خاصة في مصر. أصبح اختبار البول لتعاطي المخدرات سلاحًا لا يتجزأ في الحرب ضد المخدرات. ومن المشكلات الكبيرة في جميع اختبارات المخدرات في البول إمكانية غش العينة أواستبدالها للحصول على نتائج سلبية. الهدف من الدراسة: دراسة التاثير الكمى والنوعى لخمسة مواد شائبة على عينات البول الإيجابية للترامادول.

طريقة البحث: أجريت الدراسة على عينات بول جمعت من المترددين على معمل السموم الاكلينيكية بمستشفيات جامعة سوهاج. تم اختبار العينات للتأكد من سلامتها عن طريق فحص الاس الهيدروجينى والكثافة النوعية والكرياتينين. تم اختبار العينات بواسطة جهازالمقايسة المناعية تم تم تأكيدها وتحديدها كمياً بواسطة جهاز الكروماتوجرافيا السائلة ذات الكفاءة العالية . النتائج: أظهرت عينات البول المغشوشة بالخل والصابون اليدوي السائل ومنظف الدرانو نتائج سلبية خاطئة عن طريق اختبار المقايسة المناعية

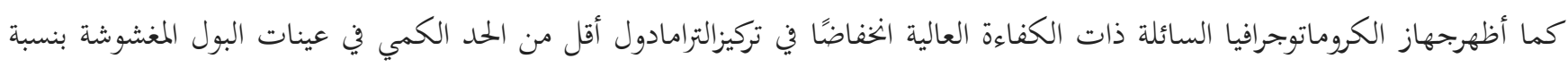

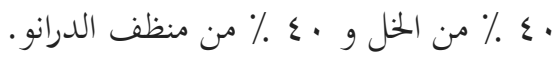

الخلاصة: اضافة بعض المواد الشائبة المى عينات البول الايجابية للترامادول يؤدى الى نتائج سلبية خاطئة واختبارات سلامة العينات قد تكون غير كافية للتعرف على هذه المواد. 